\title{
Phosphatase Activity and Phosphorus Use Efficiency of Cowpea as Influenced by Genotypes, Phosphorus Levels and Liquid based PSB
}

\author{
M.S.R. Kalyani and Ganajaxi Math* \\ Department of Agronomy, College of Agriculture, UAS, Dharwad-580005, Karnataka, India \\ *Corresponding author
}

Keywords

Cowpea genotypes, Phosphorus levels, Liquid based PSB, Seed yield

\section{Article Info}

\section{Accepted:}

15 January 2021

Available Online:

10 February 2021
A field experiment was conducted to evaluate the phosphatase activity and phosphorus use efficiency of cowpea genotypes to phosphorus levels and liquid based PSB during kharif 2019 under rainfed condition at Main Agricultural Research Station, University of Agricultural Sciences, Dharwad. Among the genotypes, the genotype DC-15 recorded significantly higher phosphatase activity, agronomic and recovery efficiency ( $45.22 \mu \mathrm{g}$ paranitrophenol ${ }^{-1}$ soil hr $^{-1}, 8.53$ and $0.040 \mathrm{~kg} \mathrm{~kg}^{-1}$, respectively) than the genotype GC3. It was on par with the genotype KBC-9. Among the phosphorus levels, the application of $75 \mathrm{~kg} \mathrm{P}_{2} \mathrm{O}_{5} \mathrm{ha}^{-1}+$ liquid PSB @ $4 \mathrm{ml} \mathrm{kg}^{-1}$ seeds recorded significantly higher phosphatase activity $\left(53.96 \mu \mathrm{g}\right.$ paranitrophenol g ${ }^{-1}$ soil hr$\left.^{-1}\right)$ over other phosphorus levels. Whereas, higher recovery efficiency $\left(0.041 \mathrm{~kg} \mathrm{~kg}^{-1}\right)$ was recorded with the application of $25 \mathrm{~kg} \mathrm{P}_{2} \mathrm{O}_{5} \mathrm{ha}^{-1}+$ liquid PSB @ 4ml kg-1 over significantly higher over other phosphorus levels. Among the interactions, DC-15 with the application of $75 \mathrm{~kg} \mathrm{P}_{2} \mathrm{O}_{5} \mathrm{ha}^{-1}+$ liquid PSB @ 4 $\mathrm{ml} \mathrm{kg}^{-1}$ seeds recorded significantly higher phosphatase activity (59.67 $\mu \mathrm{g}$ paranitrophenol $\mathrm{g}^{-1}$ soil hr${ }^{-1}$ ) over the control and other treatments. However, the genotype DC-15 with the application of $25 \mathrm{~kg} \mathrm{P}_{2} \mathrm{O}_{5} \mathrm{ha}^{-1}+$ liquid PSB @ $4 \mathrm{ml} \mathrm{kg}^{-1}$ seeds recorded significantly higher recovery efficiency $\left(0.057 \mathrm{~kg} \mathrm{~kg}^{-1}\right)$ over the control and other treatments.

\section{Introduction}

Legumes are a vital component in Indian cropping systems owing to their ability to provide significant quantities of proteins to the vegetarian diet. Cowpea (Vigna unguiculata (L.) Walp) is a multipurpose grain legume grown commercially for its long green pods, seeds and fodder in arid and humid tropics. It is called "Vegetable meat" due to its high protein content with better biological value, bears green tender pods containing protein $(4.3 \mathrm{~g})$, carbohydrate $(8.0 \mathrm{~g})$, fats $(0.6 \mathrm{~g})$ and fiber $(2 \mathrm{~g})$ per $100 \mathrm{~g}$ of edible portion. Amino acids particularly leucine, lysine and phenylalanine contents are comparatively high in cowpea. Tender fruits contain calcium (80 
$\mathrm{mg}$ ), phosphorus (74 $\mathrm{mg}$ ) and iron (2.5 mg) per $100 \mathrm{~g}$ fresh weight (Gopalakrishnan, 2007).

Phosphorus is the most limiting soil fertility factor for pulse production in many tropical soils. It promotes root formation due to increased cell division, nodule count and in turn the crop yield. It plays a vital role in oxidation-reduction, cellular energy transfer reactions, photosynthesis, respiration and influences the efficiency of the Rhizobiumlegume symbiosis. Because, a major portion of phosphorus in the form of soluble inorganic phosphate gets rapidly immobilized and thereby, it is unavailable, when applied as chemical fertilizers. Hence, there is a necessity to minimize phosphorus loss from the soil for better crop production. When phosphorus solubilizing bacteria is used either in the form of carrier based or liquid based, it can save the crop requirement of phosphatic fertilizer.

Liquid biofertilizer formulation is the most promising and updated technology of conventional carrier-based production technology. They were considered as the best way to substitute for the conventional carrier based biofertilizers for regaining soil health, enhancing crop yields and sustainable food production in the modern agriculture. Because, the quality standards of liquid based biofertilizers are good and stable for six months. In carrier based biofertilizers, the quality was very low and the viable count was decreased by every month interval (Shravani et al., 2019). Hence, rectifying the disadvantages of carrier-based formulations, liquid formulations were developed which would be the alternative for the cost-effective sustainable agriculture.

Genotypes play a significant role in crop production and the probable yield of a genotype is determined by its genetic potential and environment. New genotypes with enhanced root traits that unleash and absorbs phosphorus from soil bound phosphorus resources may be of added value for increasing the fertilizer use efficiency. Cowpea being a leguminous crop responds more to phosphorus than nitrogen and potassium.

These facts necessitate to determine the adequate supply of phosphorus to cowpea based on field experimentation for realising the genetic yield potential of newly evolved varieties. Therefore, this study is intended to govern the response of cowpea genotypes to differential $\mathrm{P}$ and PSB applications so as to determine suitable recommendations.

\section{Materials and Methods}

The experiment was conducted during kharif 2019 under AICRP, MULLARP at MARS, Dharwad in plot no. 148 of ' $F$ ' block which is situated at $15^{\circ} 26^{\prime} \mathrm{N}$ latitude and $75^{\circ} 01^{\prime} \mathrm{E}$ longitude at an altitude of $678 \mathrm{~m}$ above mean sea level, comes under Northern Transition Zone (Zone 8) of Karnataka. The experiment was laid out in in two factorial RBD with single control design with twelve treatment combinations and replicated thrice.

The first factor consists of three genotypes (DC-15, GC-3 and KBC-9) and second factor consists of four phosphorus levels $(0,25,50$ and $75 \mathrm{~kg} \mathrm{P}_{2} \mathrm{O}_{5} \mathrm{ha}^{-1}$ ) along with liquid based PSB @ 4 $\mathrm{ml} \mathrm{kg}^{-1}$ seeds and control (DCS-471+ RDF (25:50:25) N: $\mathrm{P}_{2} \mathrm{O}_{5}: \mathrm{K}_{2} \mathrm{O} \mathrm{kg} \mathrm{ha}{ }^{-1}+$ carrier based PSB @ 500g ha ${ }^{-1}$ ).

The texture of the experimental soil was clay loam having $\mathrm{pH}$ of 7.85 and electrical conductivity of $0.32 \mathrm{dSm}^{-1}$. The soil was low in available nitrogen $\left(232.5 \mathrm{~kg} \mathrm{ha}^{-1}\right)$, medium in available phosphorus (22.6 $\mathrm{kg} \mathrm{ha}^{-1}$ ) and high in available potassium (381.9 $\mathrm{kg} \mathrm{ha}^{-1}$ ) respectively. The seeds were treated with Rhizobium @200 $\mathrm{g} \mathrm{ha}^{-1}$ (carrier based) and 
liquid PSB @ 4ml kg-1 seed. In control, seeds were treated with carrier based PSB @ $500 \mathrm{~g}$ $\mathrm{ha}^{-1}$ and Rhizobium @200 $\mathrm{g} \mathrm{ha}^{-1}$.

The spacing adopted was $45 \mathrm{~cm} \times 10 \mathrm{~cm}$. Nitrogen was applied through urea @ $25 \mathrm{~kg}$ $\mathrm{ha}^{-1}$ along with potassium as Murate of Potash (MOP)@ $25 \mathrm{~kg} \mathrm{ha}^{-1}$ uniformly to all the treatments. Phosphorus was applied through Single Super Phosphate (SSP) @ (0, 25, 50, $\left.75 \mathrm{~kg} \mathrm{ha}^{-1}\right)$ as per the treatment requirements at the time of sowing.

Phosphatase activity $(\mu \mathrm{g})$ paranitrophenol $g$ ${ }^{-1}$ soil hr.

Phosphatase activity of soil samples were determined by following procedure of Evazi and Tabatabai (1979). One gram of soil sample was placed in $50 \mathrm{ml}$ Erlenmeyer flask to which $0.2 \mathrm{ml}$ toluene followed by four $\mathrm{ml}$ of modified universal buffer $(\mathrm{pH}$ 7.5) was added. One $\mathrm{ml}$ of para-nitro-phenol phosphate solution made in modified universal buffer was added to the flasks and the contents of the flasks were mixed by swirling for two minutes.

The flasks were stoppered and incubated at $37^{\circ} \mathrm{C}$ for one hour. After incubation, one $\mathrm{ml}$ of $0.5 \mathrm{M} \mathrm{CaCl}_{2}$ and four ml of $0.5 \mathrm{M} \mathrm{NaOH}$ were added to the flask, swirled and filtered through Whatman No. 42 filter paper.

The intensity of yellow colour developed was measured at $420 \mathrm{~nm}$ against the reagent blank by using spectrophotometer. Controls were maintained for each soil sample and were analysed by following the same procedure described above except that para-nitro-phenol phosphate solution was added after the addition of $0.5 \mathrm{M} \mathrm{CaCl}_{2}$ and $0.5 \mathrm{M} \mathrm{NaOH}$ and just before filtration. The phosphate activity in the soil samples was expressed as microgram $(\mu \mathrm{g})$ paranitrophenol $\mathrm{g}^{-1}$ soil $\mathrm{hr}^{-1}$ with reference to the standard curve prepared by using graded concentrations of P-nitro-phenol phosphate.

\section{Phosphorus use efficiency}

\section{Agronomic efficiency}

It was worked out by using the formula of Fageria et al., (2011). Expressed in $\mathrm{kg} \mathrm{kg}^{-1}$

Agronomic efficiency= Yield of fertilized - yield of unfertilized crop crop

$$
\text { Quantity of nutrient applied }
$$

\section{Physiological efficiency}

It was worked out by using the formula of Fageria et al., (2011). Expressed in $\mathrm{kg} \mathrm{kg}^{-1}$

Physiological efficiency $=$ Yield of fertilized - Yield of unfertilized

$$
\text { Crop crop }
$$

Nutrient taken up - Nutrient taken up by fertilized crop by unfertilized crop

\section{Recovery efficiency}

It was worked out by using the formula of Fageria et al., (2011). Expressed in $\mathrm{kg} \mathrm{kg}^{-1}$

Recovery efficiency $=$ Nutrient taken up - Nutrient taken up by fertilized crop by unfertilized crop

Quantity of nutrient applied

The data recorded was analysed statistically following the procedure described by Gomez and Gomez (1984). The level of significance used in ' $\mathrm{F}$ ' test was $\mathrm{P}=0.05$ and critical difference values were calculated where the ' $F$ ' test was found significant.

\section{Results and Discussion}


Soil phosphatase activity plays an important role in pant nutrition. It helps in mineralisation of organically bound phosphorus to inorganic compounds in soil. Phosphatase enzyme releases organic phosphates from phosphatic compounds which are then taken up by the plants from soil (Table 1). Results revealed that among the genotypes, the genotype DC15 recorded significantly higher phosphatase activity ( 45.22 $\mu \mathrm{g}$ paranitrophenol $\mathrm{g}^{-1}$ soil $\mathrm{hr}^{-1}$ ) than the genotype GC-3 (38.03 $\mu \mathrm{g}$ paranitrophenol $\mathrm{g}^{-1}$ soil $\mathrm{hr}^{-1}$ ). It was on par with the genotype KBC-9 (42.70 $\mu \mathrm{g}$ paranitrophenol $\mathrm{g}^{-1}$ soil $\mathrm{hr}^{-1}$ ).

Similarly, the genotype DC-15 recorded significantly higher agronomic and recovery efficiency ( 8.53 and $0.040 \mathrm{~kg} \mathrm{~kg} \mathrm{~kg}^{-1}$, respectively) than the genotype GC-3 (3.07 and $0.016 \mathrm{~kg} \mathrm{~kg}^{-1}$, respectively). It was on par with the genotype KBC-9 $(7.86$ and $0.035 \mathrm{~kg}$ $\mathrm{kg}^{-1}$, respectively) over other genotypes (Table 2). However, the genotypes did not differ significantly with respect to physiological efficiency.

Among the phosphorus levels, the application of $75 \mathrm{~kg} \mathrm{P}_{2} \mathrm{O}_{5} \mathrm{ha}^{-1}+$ liquid PSB @ $4 \mathrm{ml} \mathrm{kg}^{-1}$ seeds recorded significantly higher phosphatase activity ( $53.96 \quad \mu \mathrm{g}$ paranitrophenol $\mathrm{g}^{-1}$ soil $\mathrm{hr}^{-1}$ ) over other phosphorus levels (Table 1). Further, higher recovery efficiency $\left(0.041 \quad \mathrm{~kg} \mathrm{~kg}^{-1}\right)$ was recorded with the application of $25 \mathrm{~kg}_{2} \mathrm{O}_{5}$ $\mathrm{ha}^{-1}+$ liquid PSB @ $4 \mathrm{ml} \mathrm{kg}^{-1}$ over the application of $50 \mathrm{~kg} \mathrm{P}_{2} \mathrm{O}_{5} \mathrm{ha}^{-1}+$ liquid PSB @ $4 \mathrm{ml} \mathrm{kg}{ }^{-1}$ seeds $\left(0.025 \mathrm{~kg} \mathrm{~kg}^{-1}\right)$ and $75 \mathrm{~kg} \mathrm{P}_{2} \mathrm{O}_{5}$ $\mathrm{ha}^{-1}+$ liquid PSB @ $4 \mathrm{ml} \mathrm{kg}^{-1}$ seeds $(0.025 \mathrm{~kg}$ $\mathrm{kg}^{-1}$ ) (Table 2). Such significant values of higher recovery efficiency with the lower level of phosphorus were reported by Ahirwar et al., (2016) and Kumar and Kushwaha (2006) in pigeonpea. However, phosphorus levels did not differ significantly with respect to agronomic and physiological efficiency.

Whereas, among the interactions, the genotype DC-15 with the application of $75 \mathrm{~kg} \mathrm{P}_{2} \mathrm{O}_{5} \mathrm{ha}^{-1}$ + liquid PSB @ $4 \mathrm{ml} \mathrm{kg}^{-1}$ seeds recorded significantly higher phosphatase activity (59.67 $\mu \mathrm{g}$ paranitrophenol $\mathrm{g}^{-1}$ soil $\mathrm{hr}^{-1}$ ) over the control and other treatments (Table 1). Higher levels of phosphorus present in the applied nutrients might have resulted in higher phosphatase activity. These results are in conformity with Shravani (2018) in greengram in which, she also reported liquid based PSB recorded higher phosphatase activity over carrier based PSB which is in accordance with the results.

There was no significant difference found between the interactions in agronomic and physiological efficiencies. However, the genotype DC-15 with the application of $25 \mathrm{~kg}$ $\mathrm{P}_{2} \mathrm{O}_{5} \mathrm{ha}^{-1}+$ liquid PSB @ $4 \mathrm{ml} \mathrm{kg}^{-1}$ seeds recorded significantly higher recovery efficiency $\left(0.057 \mathrm{~kg} \mathrm{~kg}^{-1}\right)$ over the control and other treatments (Table 2). It was on par with the genotype KBC-9 with the application of $25 \mathrm{~kg} \mathrm{P}_{2} \mathrm{O}_{5} \mathrm{ha}^{-1}+$ liquid PSB @ $4 \mathrm{ml} \mathrm{kg}^{-1}$ seeds $\left(0.052 \mathrm{~kg} \mathrm{~kg}^{-1}\right)$.

The genotype DC-15 with application of $75 \mathrm{~kg}$ $\mathrm{P}_{2} \mathrm{O}_{5} \mathrm{ha}^{-1}+$ liquid PSB @ $4 \mathrm{ml} \mathrm{kg}^{-1}$ seeds recorded significantly phosphatase activity over the control and others. Whereas, the genotype DC-15 with application of $25 \mathrm{~kg}$ $\mathrm{P}_{2} \mathrm{O}_{5} \mathrm{ha}^{-1}+$ liquid PSB @ $4 \mathrm{ml} \mathrm{kg}^{-1}$ seeds recorded significantly higher recovery efficiency over the control and other treatments. 
Table.1 Phosphatase activity of cowpea as influenced by genotypes, phosphorus levels and liquid PSB

\begin{tabular}{|c|c|c|c|c|c|}
\hline \multicolumn{6}{|c|}{ Phosphatase activity ( $\mu$ g) paranitrophenol g ${ }^{-1}$ soil $\mathrm{hr}^{-1}$} \\
\hline & $\mathbf{P}_{1}$ & $\mathbf{P}_{2}$ & $\mathbf{P}_{3}$ & $\mathbf{P}_{4}$ & MEAN \\
\hline $\mathbf{G}_{1}$ & 33.27 & 40.12 & 47.80 & 59.67 & 45.22 \\
\hline $\mathbf{G}_{2}$ & 28.32 & 38.34 & 40.51 & 44.96 & 38.03 \\
\hline $\mathbf{G}_{3}$ & 30.95 & 37.69 & 44.88 & 57.26 & 42.70 \\
\hline MEAN & 30.85 & 38.72 & 44.40 & 53.96 & \\
\hline Control & \multicolumn{5}{|c|}{40.54} \\
\hline & $\mathbf{G}$ & $\mathbf{P}$ & $\mathbf{G} \times \mathbf{P}$ & \multicolumn{2}{|c|}{ Control Vs Others } \\
\hline S.Em \pm & 0.98 & 1.14 & 1.97 & \multicolumn{2}{|c|}{1.4} \\
\hline CD $(5 \%)$ & 2.9 & 3.3 & 5.7 & \multicolumn{2}{|c|}{ NS } \\
\hline
\end{tabular}

Factor 1: Genotypes (G)

$\mathrm{G}_{1}: \mathrm{DC}-15$

$G_{2}:$ GC-3

$\mathrm{G}_{3}$ : KBC-9

Control:

DCS-47-1+ RDF (25:50:25 N: $\left.\mathrm{P}_{2} \mathrm{O}_{5}: \mathrm{K}_{2} \mathrm{O} \mathrm{kg} \mathrm{ha}{ }^{-1}\right)+$ with carrier based PSB @ $500 \mathrm{~g} \mathrm{ha}^{-1}$
Factor 2: Phosphorus levels (P)

$\mathrm{P}_{1}: 0 \mathrm{~kg} \mathrm{P}_{2} \mathrm{O}_{5} \mathrm{ha}^{-1}+$ liquid PSB @ $4 \mathrm{ml} \mathrm{kg}^{-1}$ seeds

$\mathrm{P}_{2}: 25 \mathrm{~kg} \mathrm{P}_{2} \mathrm{O}_{5} \mathrm{ha}^{-1}+$ liquid PSB @ $4 \mathrm{ml} \mathrm{kg}^{-1}$ seeds

$\mathrm{P}_{3}: 50 \mathrm{~kg} \mathrm{P}_{2} \mathrm{O}_{5} \mathrm{ha}^{-1}+$ liquid PSB @ $4 \mathrm{ml} \mathrm{kg}^{-1}$ seeds

$\mathrm{P}_{4}: 75 \mathrm{~kg} \mathrm{P}_{2} \mathrm{O}_{5} \mathrm{ha}^{-1}+$ liquid PSB @ $4 \mathrm{ml} \mathrm{kg}^{-1}$ seeds 
Table.2 Agronomic efficiency, Recovery efficiency and Physiological efficiency of cowpea as influenced by genotypes, phosphorus levels and liquid based PSB

\begin{tabular}{|c|c|c|c|c|c|c|c|c|c|c|c|c|}
\hline \multicolumn{5}{|c|}{ Agronomic efficiency $\left(\mathrm{kg} \mathrm{kg}^{-1}\right)$} & \multicolumn{4}{|c|}{ Recovery efficiency $\left(\mathrm{kg} \mathrm{kg}^{-1}\right)$} & \multicolumn{4}{|c|}{ Physiological efficiency $\left(\mathrm{kg} \mathrm{kg}^{-1}\right)$} \\
\hline & $\mathbf{P}_{2}$ & $\mathbf{P}_{3}$ & $\mathbf{P}_{4}$ & MEAN & $\mathbf{P}_{2}$ & $\mathbf{P}_{3}$ & $\mathbf{P}_{4}$ & MEAN & $\mathbf{P}_{2}$ & $\mathbf{P}_{3}$ & $\mathbf{P}_{4}$ & MEAN \\
\hline $\mathbf{G}_{1}$ & 10.88 & 7.66 & 7.04 & 8.53 & 0.057 & 0.033 & 0.032 & 0.040 & 197.97 & 245.02 & 226.95 & 223.98 \\
\hline $\mathbf{G}_{2}$ & 3.34 & 2.28 & 3.58 & 3.07 & 0.014 & 0.014 & 0.019 & 0.016 & 243.07 & 121.90 & 186.92 & 183.96 \\
\hline $\mathbf{G}_{3}$ & 9.20 & 7.85 & 6.53 & 7.86 & 0.052 & 0.029 & 0.023 & 0.035 & 265.40 & 318.37 & 320.51 & 301.43 \\
\hline MEAN & 7.81 & 5.93 & 5.71 & & 0.041 & 0.025 & 0.025 & & 236.15 & 228.43 & 244.79 & \\
\hline & G & $\mathbf{P}$ & \multicolumn{2}{|c|}{$\mathbf{G} \times \mathbf{P}$} & $\mathbf{G}$ & $\mathbf{P}$ & \multicolumn{2}{|c|}{$G \times P$} & G & $\mathbf{P}$ & \multicolumn{2}{|c|}{$\mathbf{G} \times \mathbf{P}$} \\
\hline S.Em \pm & 0.82 & 0.82 & \multicolumn{2}{|c|}{1.42} & 0.003 & 0.003 & \multicolumn{2}{|c|}{0.005} & 44.82 & 44.82 & \multicolumn{2}{|c|}{77.63} \\
\hline $\begin{array}{c}\text { CD } \\
(5 \%)\end{array}$ & 2.5 & NS & \multicolumn{2}{|c|}{ NS } & 0.009 & 0.009 & \multicolumn{2}{|c|}{0.016} & NS & NS & \multicolumn{2}{|c|}{ NS } \\
\hline
\end{tabular}

\begin{tabular}{|c|c|}
\hline Factor 1: Genotypes (G) & Factor 2: Phosphorus levels (P) \\
\hline$G_{1}: D C-15$ & $\mathrm{P}_{1}: 0 \mathrm{~kg} \mathrm{P}_{2} \mathrm{O}_{5} \mathrm{ha}^{-1}+$ liquid PSB @ $4 \mathrm{ml} \mathrm{kg}^{-1}$ seeds \\
\hline $\mathbf{G}_{2}: \mathbf{G C}-3$ & $\mathrm{P}_{2}: 25 \mathrm{~kg} \mathrm{P}_{2} \mathrm{O}_{5} \mathrm{ha}^{-1}+$ liquid PSB @ $4 \mathrm{ml} \mathrm{kg}^{-1}$ seeds \\
\hline $\mathrm{G}_{3}: \mathrm{KBC}-9$ & $\mathrm{P}_{3}: 50 \mathrm{~kg} \mathrm{P}_{2} \mathrm{O}_{5} \mathrm{ha}^{-1}+$ liquid PSB @ $4 \mathrm{ml} \mathrm{kg}^{-1}$ seeds \\
\hline & $\mathrm{P}_{4}: 75 \mathrm{~kg} \mathrm{P}_{2} \mathrm{O}_{5} \mathrm{ha}^{-1}+$ liquid PSB @ $4 \mathrm{ml} \mathrm{kg}^{-1}$ seeds \\
\hline
\end{tabular}




\section{References}

Ahirwar, R. P., Mishra, U. S., Mitra, N. G. and Sirothia, P. 2016, Effect of phosphorus and biofertilizers on phosphorus use efficiency, biological N-Fixation and yield of pigeonpea (Cajanus cajan L). Int. J. Agric. Envi. Biotech., 9(6): 1039-1043.

Evazi, Z. and Tabatabai, M. A. 1979, Phosphatase in soil. Soil Biol. Biochem., 9: 167-172

Fageria, N. K., Baligar, V. C. and Jones, C. A. 2011, Growth and mineral nutrition of field crops. CRC Press, pp. 57-67.

Gomez, K. A. and Gomez, A. A. 1984, Statistical Procedure for Agricultural Research. John Willey and Sons, New York, pp. 680.
Gopalakrishnan, T. R. 2007, Vegetable Crops. New India Publishing Agency, New Delhi, 3: 181.

Kumar, A. and Kushwaha, H. S. 2006, Response of pigeonpea (Cajanus cajan) to sources and levels of phosphorus under rainfed condition. Indian. J. Agron., 51(1): 60-62.

Shravani, K. 2018, Evaluation of carrier based and liquid based biofertilizers and their application methods in green gram. $M$. Sc. Thesis., PJTSAU, Hyderabad.

Shravani, K., Triveni, S., Latha, P. C. and Chari, K. D. 2019, Evaluation of shelf life and quality of carrier and liquid based biofertilizers. Int. J. Microbiol. Res., 11(6): 1598-1601.

\section{How to cite this article:}

Kalyani, M.S.R. and Ganajaxi Math. 2021. Phosphatase Activity and Phosphorus Use Efficiency of Cowpea as Influenced by Genotypes, Phosphorus Levels and Liquid based PSB. Int.J.Curr.Microbiol.App.Sci. 10(02): 1678-1684. doi: https://doi.org/10.20546/ijcmas.2021.1002.198 